\title{
SUFI HEALING MENURUT AKADEMISI (Praktik Batatamba, Amalan dan Spiritual)
}

\author{
Fahriannor \\ UIN ANTASARI BANJARMASIN \\ e-mail: fahribjm97@gmail.com
}

\begin{abstract}
Abstrak
Kajian ini mengungkap tentang Sufi Healing menurut akademisi, yaitu praktik batatamba Arni, Amalan dan pengalaman ruhaninya dengan menggunakan studi analisis dari sisi syari'at dan tradisi sufi. Fokus kajian ini adalah bagaimana pelaksanaan Sufi Healing dari sudut seorang akademisi serta mengungkap bagaimana pengalaman spiritualnya. Hasil yang diperoleh dari kajian ini adalah bahwa praktik batatamba Arni memiliki kesamaan dengan praktik Rasulullah dalam healingnya, yaitu menggunakan media air dan tiupan. Adapun pasien yang letaknya sangat jauh. Arni menggunakan media elektronik yaitu Handphone, dengan cara dihubungkan secara langsung kepada pasien. Sedangkan bacaan-bacaan Arni dalam batatamba berasal dari ayat-ayat Al-Qur'an yang diimbangi dengan amalan-amalan sunnah. Kemudian pengalaman ruhaninya memiliki kesamaan dengan yang dialami oleh para sufi terdahulu seperti bermimpi dengan Rasulullah, Malaikat dan ulama. Oleh sebab itulah, menjadi penting bagi seorang muslim untuk memahami aspek syari'at sebelum bergerak di bidang healing atau batatamba, sehingga media dan amalan yang digunakan tidak bertentangan dengan ajaran agama Islam.
\end{abstract}

Kata Kunci: Sufi Healing, Akademisi, Batatamba, Spiritual

\section{PENDAHULUAN}

Salah satu unsur kebudayaan daerah yang diwarisi secara turun temurun adalah pengetahuan yang berkaitan dengan pengobatan tradisional. Pengobatan tradisional merupakan bagian integral kebudayaan karena konsep tentang kondisi sakit dan cara pengobatannya tidak berdiri sendiri. Perkembangan ilmu pengetahuan dan teknologi yang semakin pesat tetap tidak mampu menggeser arti pengobatan tradisional. Tidak jarang masyarakat memilih pengobatan tradisional yang dianggap memiliki efek samping lebih kecil, ${ }^{1}$ seperti terapi Al-Qur'an, ${ }^{2}$

\footnotetext{
${ }^{1}$ Asmawati, Zaenap Hartati dan Emawati, Makna Pengobatan Tradisional Badewah Suku Dayak Bagi Masyarakat Muslim di Kalimantan Tengah, Jurnal IAIN Palangka Raya Studi Agama-agama, Volume 8, Nomor 1, 2018, 83-84.

${ }^{2}$ Abdullah Al- Sadhan, Cara Pengobatan Dengan Al- Qur'an diterjemahkan oleh Muzaffar Sahidu dari كيف تعالج مريضم بالرقبة الثرعية (Indonesia: ttp, 2009), 22.
}

Al Qalam: Jurnal Ilmiah Keagamaan dan Kemasyarakatan Vol. 16, No. 1 Januari - Juni 2022 
pengobatan herbal, pengobatan holistik, pengobatan spiritual, dan ada pula yang menyebut istilah sufi healing. ${ }^{3}$

Diantara masyarakat yang sering terlibat dalam pengobatan tradisional adalah suku Banjar. Suku Banjar merupakan suku terbesar di Kalimantan Selatan. Dalam kehidupannya, Suku Banjar memiliki pengetahuan yang unik terhadap sakit dan penyembuhnya, untuk keduanya mereka biasa menyebutnya garing dan penamban. Pengobatan tradisional pada masyarakat Banjar yang disebut dengan istilah batatamba memiliki keunikan tersendiri. Menurut orang Banua, sakit adalah semacam gangguan terhadap pikiran dan fisik manusia, sehingga ia tidak dapat melaksanakan pekerjaan dengan baik. Dengan kata lain, sakit adalah gangguan yang menyerang manusia, baik secara lahir dan batin. Dengan dasar ini, sakit dibedakan menjadi dua bagian, yaitu sakit yang bersifat nyata (rasional, ringan) dan sakit yang bersifat tidak nyata (irrasional, berat). Sakit yang nyata adalah penyakit yang dapat dilihat dan dirasakan dengan jelas sehingga mudah untuk diobati. Sedangkan sakit yang tidak nyata adalah penyakit yang sulit untuk ditemukan penyebabnya. Orang yang sakit juga tidak dapat menyebutkan bagian mana yang terasa sakit karena yang merasakan sakit adalah fisik dan psikisnya, baik secara sadar maupun tidak. ${ }^{4}$

Ajaran Islam Bukanlah satu-satunya referensi bagi kelakuan religious orang Banjar, begitu pula dengan ritus dan upacara yang dijalankan. Itulah sebabnya, kepercayaan terhadap unsur magis dunia gaib tidak bisa dilepaskan dari keseharian hidup masyarakat Banjar. ${ }^{5}$

Transformasi tersebut juga menyentuh kepercayaan dan pemahaman terhadap berbagai ritus yang lain, termasuk batatamba. Apabila sebelum Islam datang untuk ritual pengobatan tersebut dibacakan mantera (bamamang), maka kemudian ia berubah dan dibacakan doa sebagai penggantinya atau ditambahkan kalimat syahadat pada akhir mantra; penggunaan ukiran kaligrafi yang menggantikan simbol penolak bala; wafak yang bertuliskan ayat-ayat Alquran; Yasin untuk penghalat (pembatas) agar terhindar dari gangguan makhluk gaib, dan sebagainya. Ini merupakan sebuah penanda bagaimana dakwah (dakwah kultural) dilakukan, yakni dengan melakukan perubahan-perubahan tertentu terhadap suatu kebiasaan masyarakat sebelum Islam agar tidak menyimpang dari ajaran Islam atau kemudian mengganti dan memasukkan ajaran Islam ke dalamnya. Dalam istilah sekarang disebut dengan akulturasi, transformasi, atau dialektika, yakni

${ }^{3}$ M. Amin Syukur, SUFI HEALING; Terapi dalam Literatur Tasawuf, Jurnal IAIN Walisongo Semarang Volume 20, Nomor 2, 2012. 392.

${ }^{4}$ M. Arli Rusandi dan Ledya Oktavia Liza, Nilai-nilai Batatamba Masyarakat Banjar Bantaran Sungai dalam Mengatasi Gangguan Psikologis (Gelisah dan Gangguan Tidur) kedalam Bimbingan dan Konseling, Jurnal Universitas Negeri Semarang, 2017, 320.

${ }_{5}^{5}$ Madya dan Awang Azman, Warisan dan Sumber: Pengertian Sejarah, Budaya dan Alam Borneokalimantan (Malaysia: Bumi Serasi, 2012), 302.

Al Qalam: Jurnal Ilmiah Keagamaan dan Kemasyarakatan Vol. 16, No. 1 Januari - Juni 2022 
usaha untuk mempertemukan budaya, kebiasaan atau adat laku masyarakat lokal dengan ajaran Islam. ${ }^{6}$ Hal tersebut dilakukan oleh para sufi agar ajaran Islam bisa diterima secara perlahan terutama ketika Islam menyebar pertama kali di Nusantara.

Dalam perkembangannya ada banyak tokoh yang mampu melakukan batatamba di masyarakat banjar, mulai dari orang awam (biasa), ulama, hingga akademisi. Diantara tokohnya ialah Arni yang merupakan dosen di UIN Antasari Banjarmasin. Arni adalah seorang akademisi, diamana kesehariannya tidak hanya aktif dalam Batatamba, dirinya juga aktif sebagai dosen Fakultas Ushuluddin dan Humaniora, serta dirinya juga aktif dalam menulis beberapa karya jurnal ilmiah yang diterbitkan dari berbagai pihak.

Hal ini menjadi menarik, dimana pada umumnya seorang yang ahli batatamba merupakan ulama ataupun orang biasa akan tetapi dianggap mampu oleh masyarakat setempat dikarenakan bebearapa faktor, salah satunya seperti ada memiliki garis keturunan yang mampu melakukakan Batatamba atau semacamnya. Berbeda dengan Arni, dimana pada sebagian besar seorang Akademisi jauh dari hal-hal tersebut, karena seringkali akademisi dianggap lebih mengedepankan akal pikiran maupun rasio yang membuat mereka menjauhi dari hal-hal berbau mistis.

Berdasarkan latar belakang ini, dapat dirumuskan beberapa permasalahan penting yang akan dikaji dalam penelitian ini; Pertama, Bagaimana bentuk dan metode batatamba Arni?, Kedua, apa saja bacaan yang diamalkan dan amplikasinya pada spiritual?

Adapun data dan sumber data yang digali dalam penelitian ini terdiri dari data pokok (primer) yaitu data pokok yang diperoleh dari sumber asli, yakni data mengenai batatamba dan Sufi Healing serta data pelengkap (sekunder), yaitu data pokok yang memuat informasi tambahan mengenai gambaran daerah penelitian. Sumber data responden adalah Arni yang dapat memberikan informasi data pokok secara langsung kepada peneliti.

Teknik pengumpulan data dilakukan dengan observasi, wawancara dan dokumentasi, yakni mengumpulkan dokumen-dokumen sesuai dengan data yang diperlukan, kemudian dianalisis dengan teknik deskriptif kualitatif, yaitu setelah data dikumpulkan, direvisi, diklasifikasi, kemudian diuraikan data tersebut sesuai dengan pokok permasalahannya ke dalam uraian-uraian yang disusun secara sistematis.

\section{METODE PENELITIAN}

Penelitian ini menggunakan metode kualitatif dengan jenis penelitian fenomenologi. Dalam tekhnik pengumpulan data peneliti menggunakan wawancara terstruktur dan depth interview

${ }^{6}$ Zulfa Jamalie dan Muhammad Rif'at, Dakwah Kultural (Dialektika Islam dan Budaya dalam Tradisi Batatamba), Jurnal IAIN Antasari Banjarmasin ALHADHARAH, Volume 11, Nomor 21, $2012,52$.

Al Qalam: Jurnal Ilmiah Keagamaan dan Kemasyarakatan Vol. 16, No. 1 Januari - Juni 2022 
terhadap beberapa temuan yang perlu didalami oleh peneliti. Data kemudian dianalisis dengan menggunakan model Miles and Hubberman yaitu dengan cara mereduksi data, mendisplay data sesuai dengan katagorisasinya serta selanjutnya dilakukan verifikasi data.

\section{PEMBAHASAN}

1. Metode Penyembuhan Dalam Islam

Pandangan fundamental umat Islam terkait penyakit dan peyembuhnya berada pada kawasan keyakinan mereka, yakni kepercayaan bahwa munculnya penyakit dan kesembuhan bersumber dari Allah Swt. Dalam suatu hadits disebutkan sebagai berikut :

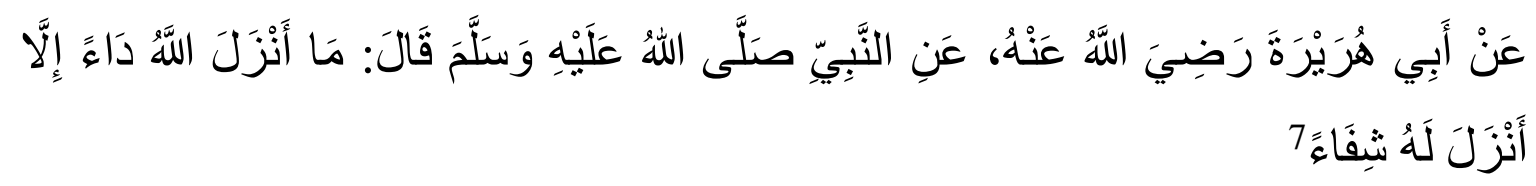

Artinya: Dari Abu Hurairah, dari Rasulullah Saw bersabda; Tidaklah Allah Swt menurunkan suatu penyakit melainkan Allah turunkan pula penyembuhnya.

Keyankinan demikian inilah yang dipercaya oleh umat Islam dalam menyikapi suatu penyakit, mereka dituntut besabar dan berusaha. Teori lain yang berkembang dalam paradigma umat muslim terkait pengobatan adalah petunjuk yang berasal dari al-Qur'an, yakni bahwa al-Qur'an selain sebagai petunjuk, tetapi juga berguna sebagai obat atau penawar, ${ }^{8}$ sebagaimana firman Allah Swt yang berbunyi :

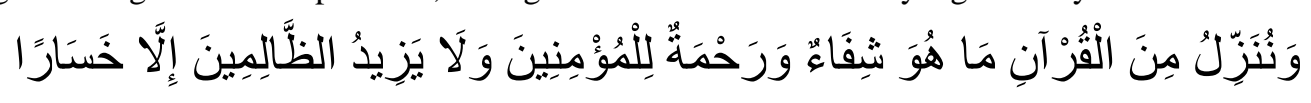

Artinya: Dan Kami turunkan al-Qur'an menjadi obat penawar dan Rahmat untuk orang-orang yang beriman dan al-qur'an itu tidaklah menambah kepada orang-orang zalim selain kerugian. (Q.S Al-Isra`: 82)

Dan ayat lain dalam firman Allah yang berbunyi :

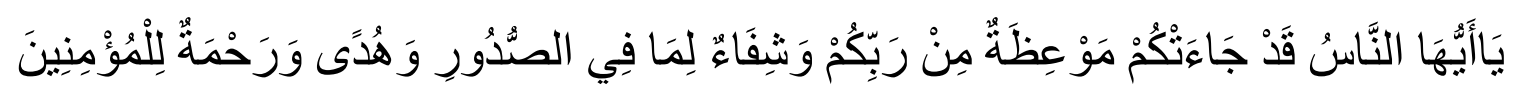

Artinya: Wahai Manusia, telah datangn kepadamu kitab yang berisi pelajaran dari Tuhanmu dan sebagai obat penyembuh, sebagai petunjuk dan rahmat bagi orang-orang yang beriman. (Q.S Yunus: 57)

Secara eksplisit, makna yang termuat pada ayat ini adalah bahwa al-Qur'an yang tersusun dalam rangkaian huruf, ayat, dan surah ternyata memiliki fungsi sebagai penyembuh bagi mereka

122.

${ }^{7}$ Muhammad Bin Ismâ'’̂ll Al-Bukhârî, Shahîh Al-Bukhârî Jilid 7 (Beirut: Dâr Thûq An-Najâh, 1422),

${ }^{8}$ Syaifan Nur, Sufi Healing Praktek Pengobatan Spiritual Di Desa Cangkrep Kabupaten Purworejo, Jurnal Refleksi, Vol. 15, No.1, 2015, 90. Sebagaimana mengutip dari Ibnul Qayyim Al-Jauziyah, Sistem Kedoktoran Nabi; Kesehatan dan Pengobatan Menurut Petunjuk Nabi Muhammad Saw (Semarang: DIMAS, 1994), 39.
Al Qalam: Jurnal Ilmiah Keagamaan dan Kemasyarakatan Vol. 16, No. 1 Januari - Juni 2022 
yang mau menggunakannya, baik dengan membaca maupun memahami isyarat-isyarat medis yang terdapat didalamnya.

Setidaknya terdapat dua pendapat dalam memahami ayat-ayat di atas; pertama, pandangan yang menyebutkan bahwa penyakit yang dijelaskan al-Qur'an adalah penyakit yang berkaitan dengan hati atau jiwa. Sedangkan pandangan kedua, penyakit yang bisa disembuhkan oleh alQur'an tidak hanya terbatas pada penyakit hati, melainkan juga penyakit-penyakit yang nampak. Hal ini didasarkan pada beberapa sabda Rasulullah Saw sebagai berikut:

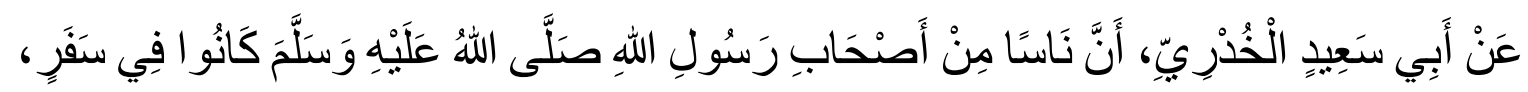

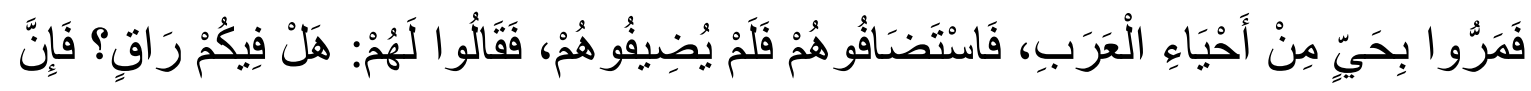

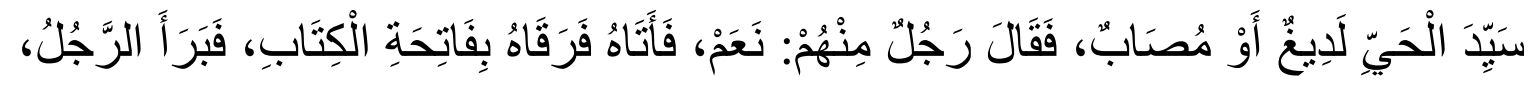

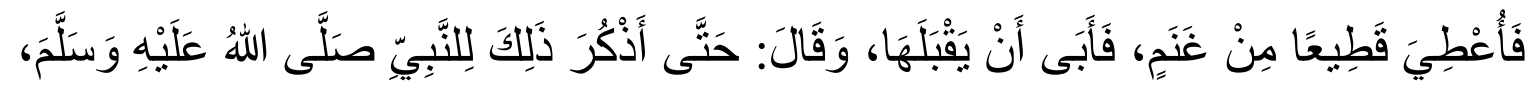

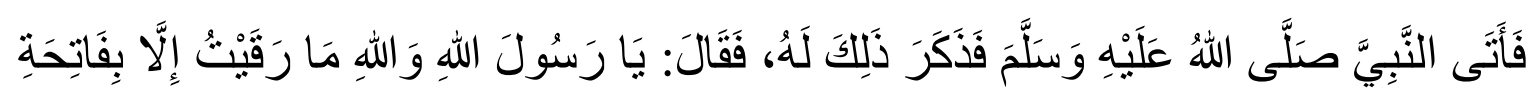

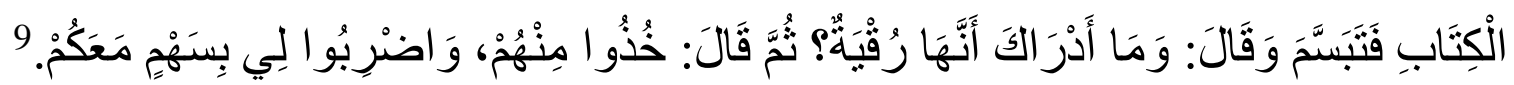

Artinya: Dari Abu Sa'is A;-Khudrî; Bahwa sekelompok sahabat Nabi pernah mengunjungi salah satu perkampungan Arab, tuan rumah daerah itu tidak mau menjamu mereka. Dalam keadaan demikian, tiba-tiba pemimpin kaum itu disengat binatang berbisa. Kaum itu berkata kepada mereka:"Apakah kalian mempunyai obat atau seorang yang bisa meruqyah? Mereka menjawab:"Sesungguhnya kalian tidak mau menjamu kami. Kami tidak akan membantu kalian sampai kalian memberi kami upah”. Maka mereka pun memberikan beberapa ekor kambing. Salah seorang sahabat kemudian membaca surat Al Fatihah dan mengumpulkan air ludahnya kemudian meludahi (pemimpin yang tersengat tadi). Ia pun sembuh. Merekapun memberikan kambing. Lalu para sahabat berkata, "Kita tidak akan mengambilnya sampai kita bertanya dahulu kepada Nabi Shallallahu 'Alaihi Wasallam”. Mereka bertanya kepada Nabi tentangnya. Beliaupun tertawa dan bertanya:" Apa yang membuatmu tahu bahwa (Al Fatihah) adalah ruqyah? Ambillah kambing itu dan berikanlah aku sebagiannya.

Dalam Hadist lain disebutkan sebagai berikut:

${ }^{9}$ Muslim, Shahîh Muslim Jilid 4 (Beirut: Dâr Ihyâ` At- Turâts Al-“Arabîy, t.th), 1721.

Al Qalam: Jurnal Ilmiah Keagamaan dan Kemasyarakatan Vol. 16, No. 1 Januari - Juni 2022 


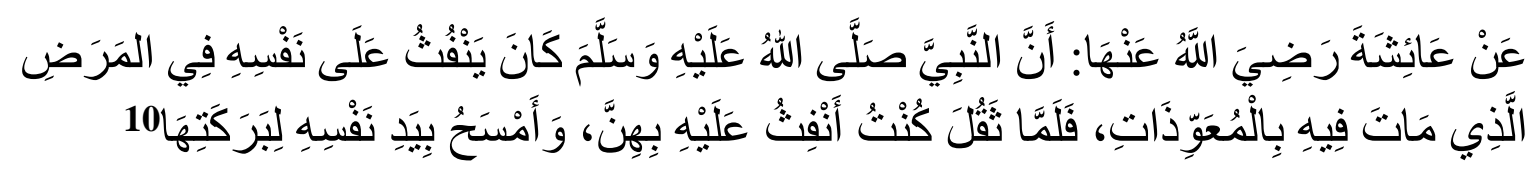

Artinya : "Bahwa Rasûlullâh SAW ketika hendak tidur, beliau meniupkan ke kedua tangannya sambil membaca dua surat perlindungan (surat al-Nâs dan al-Falaq), lalu beliau mengusapkan ke badannya." (HR. Imam al-Bukhārī)

Begitu pula dalam riwayat lain di sebutkan sebagai berikut:

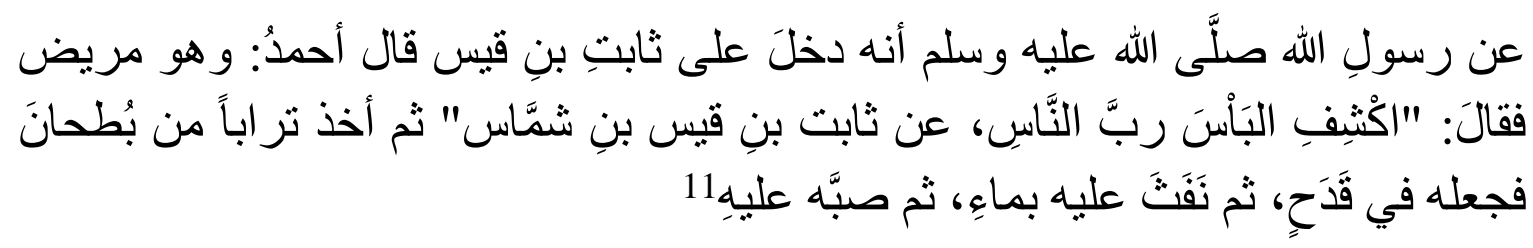

Artinya: Raslullah menemui Tsabit bin Qais yang sedang sakit, kemudian berdoa "Hilangkanlah penyakit dari Tsabit bin Qais", setelah itu rasulullah mengambil debu tanah dari Buthan lalu memasukkannya ke dalam gelas, selanjutnya menyemburkan air ke dalamnya pula dan menuangkan kepada Tsabit bin Qais.

Dari hadits-hadits diatas menunjukan bahwa penyakit yang diterangkan tersebut bersifat umum dan tidak terbatas pada penyakit-penyakit hati, akan tetapi memuat pula penyaki-penyakit yang bersifat global.

2. Amalan dan Spiritual Sufi

Proses batatamba tidak hanya mengandalkan bacaan dari ayat-ayat suci al-Qur'an, sebab banyak di kalangan pemula yang hanya bermodalkan suara dan keberanian saja namun tidak bisa mengatasi persoalan di lapangan. Adapun aspek lain yang harus diperhatikan dalam batatamba ialah ketaqwaan dan kesalehan pribadi, termasuk pula keikhlasan dalam menjalankannya. ${ }^{12}$

Diantara upaya agar bisa memperoleh ketaqwaan dan kesalihan pribadi ialah dengan mensucikan pribadi dari sifat-sifat buruk, baik itu perbuatan buruk yang bersifat nampak maupun yang tersembunyi, konsep ini disebut dengan istilah takhalli. Segala sifat buruk yang mencemari hati diantaranya ialah iri hati, medongkol, prasangka buruk, angkuh, memuliakan diri, riya , pelit, pemarah dan lain-lainnya. Kemudian setelah pribadi sebelumnya telah dibersihkan dan disucikan

${ }^{10} \mathrm{Abu}$ 'Abdullah Muhammad bin Ismāīl al-Bukharī, Al-Jāmī' Al-Shahīh, Volume IV (Kairo: alMathba'ah as-Salafiyyah, 1400). 42

${ }^{11}$ Abū Dāud Sulaiman, Sunan Abi Dāud Jilid 6 (Lebanon: Dār Ar-Risālah Al-'Ālamiyah, 2009), 34.

${ }^{12}$ Arni, Implementasi Ruqyah Syar'iyah Sebegai Alternatif Psikoterapi Dalam Kajian Psikologi Islam, Jurnal Studia Insania, Vol. 9, No.1, 2021, 16-17.

Al Qalam: Jurnal Ilmiah Keagamaan dan Kemasyarakatan Vol. 16, No. 1 Januari - Juni 2022 
pada tahapan takhalli, maka secara bersamaan dilakukan pula menghiasi pribadi dengan segala macam sifat terpuji secara nampak maupun batin. Ketika manusia berhasil pada tahapan ini, maka dia akan menjadi seseorang yang dapat menerima cahaya Ilhai (tajalli), sehingga apapun yang dia kerjakan semuanya murni dan ikhlas karena Allah Swt. Dalam tingkatan ini (tajalli), hati seorang manusia akan bercahaya dan terbuka luas, sehingga tersingkaplah dinding rahasia alam malakut melalui karunia-Nya. Ketika itu nampaklah segalah hakikat yang sebelumnya tertutupi oleh kotoran jiwa. ${ }^{13}$

Menurut Alfiyah Laila melalui jurnalnya, dia berpendapat bahwa takhalli, tahalli dan tajalli yang sebagaimana telah dikonsepkan oleh al-Ghazali merupakan prosuder penting dalam upaya melaksanakan ruqyah/batatamba. Dengan demikian, ruqyah/batatamba mempunyai pengaruh yang besar dan signifikan terhadap pasien yang sedang menderita penyakit tersebut. ${ }^{14}$

\section{Biografi singkat Arni}

Arni dilahirkan didesa Jarang Kuantan Amuntai Selatan pada hari Jum'at 10 November 1962 M atau bertepatan 12 Jumadil Akhir 1382 H. Dirinya dididik dari kalangan sederhana, dia mengenyam pendidikan di Madrasah Ibtidaiyah Nur Hidayah selama enam tahun, kemudian melanjutkan ke Tsanawiyah Amuntai tiga tahun, selanjutnya SMA Amuntai tiga tahun dan perguruan tinggi IAIN Antasari Banjarmasin jurusan Perbandingan Agama yang diselelsaikan pada tahun 1988. Setelah itu dirinya mendaftar masuk di sarjana penggerak pendesaan selama dua tahun, setelah itu mendaftar dan masuk di penerimaan dosen IAIN Antasari Banjarmasin hingga sekarang. Dirinya pernah mengajar mata kuliah Aliran kepercayaan. ${ }^{15}$

\section{Bentuk dan Metode Batatamba Pak Arni}

Menurut Arni dalam praktik Batatamba selama ini ada yang berhasil dan juga tidak, hal itu menurutnya menjadi wajar karena dirinya hanya mendoakan. Adapun kesembuhan ataupun keberhasilan sendiri berasal dari Allah Swt. Dia mengatakan ada penyakit atau gangguan yang disebabkan oleh Jin, baik itu karna dari diri pasien sendiri atau berasal dari kiriman oleh orang lain, namun ada juga memang berasal dari azab Allah Swt. Untuk bagian yang terakhir ini adalah hal yang paling sulit untuk disembuhkan menurutnya.

\footnotetext{
${ }^{13}$ Asmaran, Pengantar Studi Tasaawuf (Jakarta: PT RajaGrafindo Persada, 1996), 66-73.

${ }^{14}$ Alfiyah Laila Afiyatin, Ruqyah Sebagai Pengobatan Berbasis Spiritual Untuk Mengatasi Kesurupan, Jurnal HISBAH, Vol. 16, No. 2, 2019, 224.

${ }^{15}$ Wawancara pribadi dengan Arni, Banjarmasin tanggal 24 Desemer 2020.
}

Al Qalam: Jurnal Ilmiah Keagamaan dan Kemasyarakatan Vol. 16, No. 1 Januari - Juni 2022 
Adapun dalam praktik batatambanya, bisa dilakukan dengan jarak dekat yaitu melalui media Air. Air tersebut dibacakan, lalu diminum atau dimandikan oleh pasien sendiri, atau bisa juga melalui bacaan secara langsung kepada pasien lalu ditiupkan. Kemudian cara berikutnya adalah dengan jarak jauh yaitu melalui telepon seluler, biasanya ini terjadi pada pasien yang tidak mungkin bertemu secara langsung dikarenakan jarak yang sangat jauh, seperti saat dirinya pernah ditelpon oleh orang-orang dari berbagai Negara, diantaranya dari Belanda, Mesir, Madinah, Mekkah, Tiongkok, Brunai dan maupun dalam Negeri seperti Jakarta terutama yang seringkali menghubunginya. Ada juga yang sebenarnya bisa saja bertemu secara langsung, tetapi memerlukan waktu yang cukup lama, seperti orang yang sedang kesurupan atau semacamnya yang mengharuskan adanya tindakan segera sehingga tidak bisa ditemui secara langsung.

Adapun bacaan-bacaan terhadap pasien secara umum yaitu surah Al-Fatihah, Ayat Kursiy, surah Al-Falaq, dan Surah An-Nâs, ditambah bacaan-bacaan tertentu sesuai kondisi masalah yang di hadapi pasien. Arni sendiri tidak mengungkapakan lebih lanjut apa bacaan-bacaan tertentu tersebut ketika menghadapi kondisi masalah pasien yang berbeda-beda, namun dirinya memastikan bacaan tersebut tetap berasal dari Al- Qur'an. ${ }^{16}$

Lebih lanjut Arni menjelaskan Batatamba ada tiga macam, yakni untuk kesembuhan, pembentengan dan keberhasilan. Pada dasarnya kesembuhan adalah sesuatu yang sudah diketahui dan jelaskan sebelumnya, yakni untuk pasien yang memiliki penyakit medis ataupun non medis. Adapun untuk pembentengan ialah agar pasien terlindungi dari gangguan-gangguan Jin, seperti kesurupan, Bagampiran ${ }^{17}$ atapun yang lainnya. Sedangkan keberhasilan yaitu untuk sebuah usaha atau kehidupan manusia pada umumnya seperti berdagang, berbisnis, ataupun hubungan keluarga yang tidak harmonis seperti salah satu kasusnya ada seorang pasien perempuan yang mengadukan suaminya yang sering memukul dirinya. ${ }^{18}$

Sebagaimana telah dijelaskan bahwa secara umum dari tiga macam praktik batatamba diatas, memiliki bacaan-bacaan yang sama terhadap pasien, namun ada satu praktik yang sedikit berbeda diantara tiga macam tersebut, yakni pembentengan. Menurut Arni dari sekian banyak pasien yang datang, ada salah satunya yang mengaku sangat sering mengalami kesurupan hingga terjadi setiap hari, bahkan dalam sehari terjadi bisa empat kali. Pasien seperti ini ditangani sedikit

\footnotetext{
${ }^{16}$ Wawancara pribadi dengan Arni, Banjarmasin tanggal 19 Desember 2020.

${ }^{17}$ Bagampiran adalah Hubungan kekerabatan antara manusia dengan orang gaib yang pada umumnya terjadi karena ada hubungan darah (Keturunan). Lihat Arni, Kepercayaan Bagampiran Antara Manusia dengan Makhluk Gaib Di Amuntai, Jurnal Ilmu Ushuluddin, Volume 9, No. 1, Januari 2010, 26.

${ }^{18}$ Wawancara pribadi dengan Arni, Banjarmasin tanggal 24 Desemer 2020.
}

Al Qalam: Jurnal Ilmiah Keagamaan dan Kemasyarakatan Vol. 16, No. 1 Januari - Juni 2022 
berbeda, tidak hanya memberikan air yang telah dibacakan kepada pasien sebagai medianya, tetapi juga memberikan sebuah amaliyah terhadap pasien tersebut. Amalan tersebut dinamai Wirid Al$A$ 'la, amalan ini sebenarnya tidak hanya diperuntukkan kepada orang yang kesurupan, namun bisa juga kepada hal-hal yang lain seperti untuk perlindungan diri dari gangguan jin secara umum.

Berikut bacaan Wirid Al A'la, dibaca setelah shalat magribh :

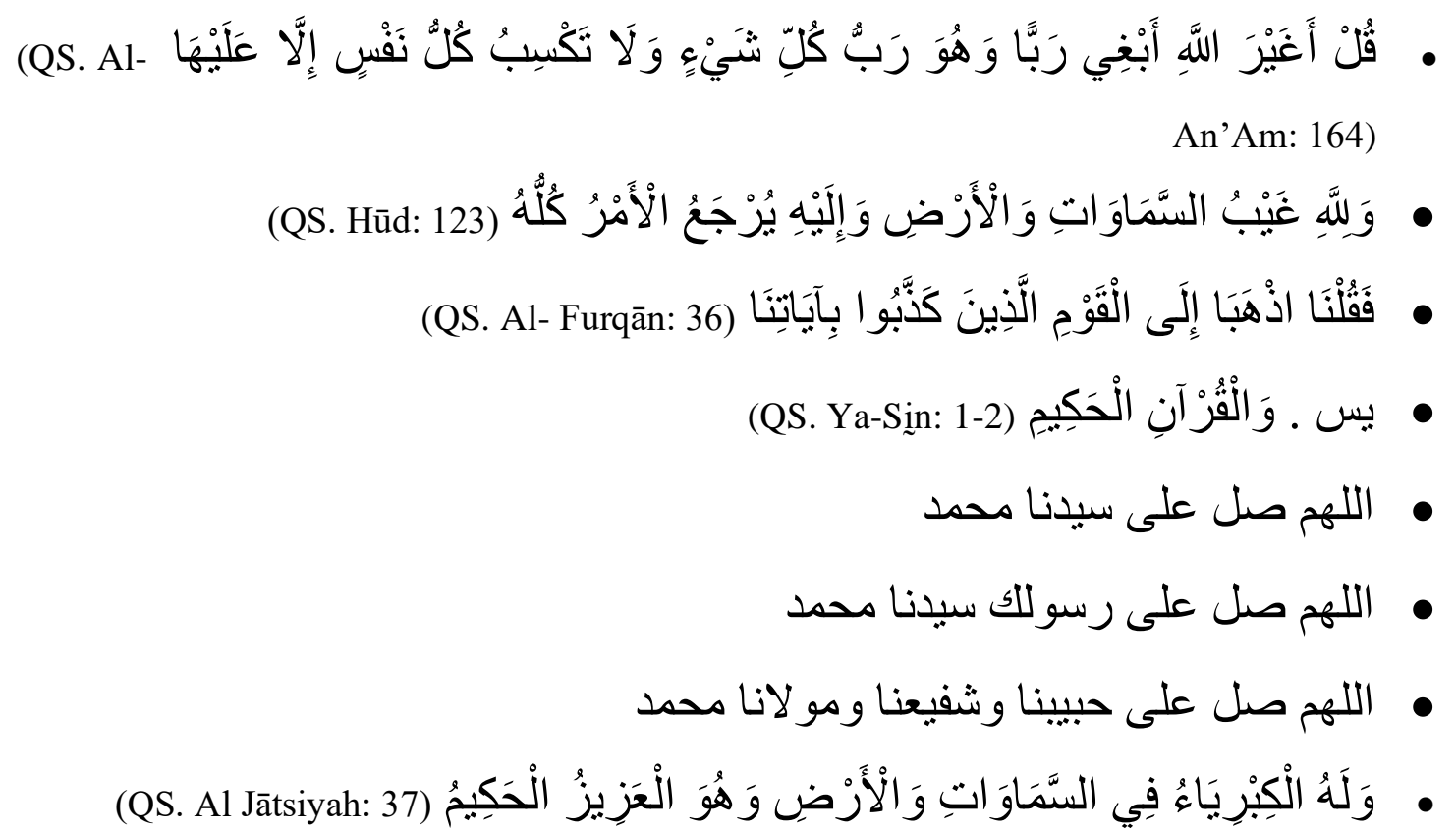

Menurut Arni, amalan ini tidak hanya sekedar dibaca oleh pasien, tetapi pasien juga harus disyaratkan melaksanakan kewajiban yang diperintah Allah Swt dan menjauhi segala larangan-Nya serta memperbanyak amalan-amalan Sunat. Amalan ini di dapat ketika dirinya telah melaksanakan khalwat kurang lebih selama tiga tahun. Setelah di dapat, dia tidak langsung mengajarkan, tetapi menunggu terlebih dahulu beberapa saat agar tidak tergesa-gesa.

5. Amalan dan Implikasinya pada Spiritual

Pada Tahun 1985 Arni sering belajar Ilmu kebathinan, hampir semua guru yang beliau kunjungi mengamalkan Sholat Tahajud baik itu dengan Asmaul Husna maupun dengan Sholawat. Arni mengaku bahwa dirinya tidak ada memiliki keturunan yang bisa melakukan Batatamba. Dia bisa melakukan hal tersebut dengan sendirinya, namun sebelum itu beliau sering melaksanakan Khalwat mulai tahun 1995 dari pukul 2 pagi hingga siang, diantara amalan-amalannya berupa ibadah-ibadah sunat, seperti Sholat Israq, Dhuha, Rawatib, Taubat, Awabin dan Tahajud, serta bacaan-bacaan lainnya seperti Dzikir dan Sholawat sebanyak 15.000 selama 3 tahun. Selain itu

Al Qalam: Jurnal Ilmiah Keagamaan dan Kemasyarakatan Vol. 16, No. 1 Januari - Juni 2022 
beliau juga sering melaksanakan Sujud Sajadah selama 4 tahun setiap Subuh, dari situ beliau sudah mulai bisa Batatamba. ${ }^{19}$

Selain itu dia bercerita ketika pernah ditanya oleh pak Abdul Wahid salah satu Dosen Fakultas Ushuluddin dan Humaniora jurusan Perbandingan Agama, beliau ditanya tentang siapa Presiden Selanjutnya, pada saat itu Presiden masih dijabat oleh B. J. Habibie, lalu beliau langsung berkata Gusdur. Di saat itu Gusdur dianggap tidak memiliki bayangan sebagai Presiden karena diluar 6 poros, yakni Amien Rais, Yusril, Megawati, Hamzah Haz dan lainnya. Ketika Gusdur naik sebagai Presiden, dirinya terkejut dan menangis karna merasa takut barangkali apa yang dia katakan sebelumnya berasal dari bantuan Jin, padahal dirinya tidak pernah melakukan hubungan dengan jin, membaca mantra-mantra ataupun semacamnya.

Setelah itu ketika waktu Magribh tiba, dirinya melaksanakan sholat maghrib sepertia biasa, namun setelah melaksanakan sholat tersebut dirinya sedang berada antara terjaga dan tidur, ketika itu dirinya bertemu dengan beberapa malaikat, yaitu Jibril, Mika'il dan Israfil yang berwujud sebagai manusia dan Izrail yang berwujud sebagai awan. Menurut Arni hal tersebut dikuatkan ketika dirinya terbangun dan tanpa ada sesuatu, tiba-tiba dirinya membuka buku yang menceritakan tentang malaikat. Hal ini menurutnya menunjukkan bahwa apa yang dia katakan tentang kebenaran Gusdur sebagai Presiden berikutnya bukan berasal dari jin, tetapi malaikat. Disamping pernah berjumpa dengan malaikat, dirinya juga mengaku pernah bermimpi Rasulullah Saw sebanyak tujuh kali dan bermimpi dengan Guru KH Zaini bin Abdul Ghani (Guru Sekumpul) sebanyak enam kali. ketika bermimpi Rasulullah, dirinya diajarkan mengaji Al-Qur'an.

Menurut Arni semua yang dialaminya bukanlah hal yang mudah, semua memiliki proses, usaha dan tawakkal yang kuat kepada Allah Swt. selain Khalwat, kunci dari semua hal itu adalah istiqamah, dimana dirinya mewajibkan amalan-amalan sunnat, sehingga hampir tidak pernah tertinggal. Bahkan ketika amalan tersebut tertinggal ataupun terlewat karna sesuatu, dirinya membayar ketika keesokan harinya sebanyak apa yang telah dia tinggalkan sebelumnya. Namun dirinya juga mengingatkan hal yang penting, dimana semua amalan dan sholat sunnat itu mesti diniatkan ikhlash kepada Allah Swt tanpa ada unsur dunia sedikitpun, karena menurutnya, jika seseorang melaksanakan amalan-amalan sunnat atau ibadah sunnat lainnya dengan niat keduniaan, maka yang datang kepadanya bukanlah malaikat, tetapi Jin. ${ }^{20}$

\footnotetext{
${ }^{19}$ Wawancara pribadi dengan Arni, Banjarmasin tanggal 19 Desember 2020.

${ }^{20}$ Wawancara pribadi dengan Arni, Banjarmasin tanggal 24 Desemer 2020.
Al Qalam: Jurnal Ilmiah Keagamaan dan Kemasyarakatan Vol. 16, No. 1 Januari - Juni 2022


Disamping itu, menurutnya ketika seseorang mampu melakukan batatamba terhadap pasien yang memiliki gangguan jin, sepantasnya dia selalu menjaga amalan-amalan sunnatnya agar bisa istiqamah, sebab jika tidak, dia akan mendapat gangguan jin yang berasal dari sekian banyak pasien yang telah dia tolong sebelumnya. Karna kekuatan seorang hamba dalam batatamba tidak hanya cukup dengan ibadah wajib saja, mesti diikuti dengan ibadah-ibadah sunnat lainnya agar pondasi atau dasarnya dalam batatamba juga kokoh dan kuat sehingga tidak akan megalami gangguan jin dari sekian banyak pasien yang dia tangani.

Diantara amalan-amalan rutinnya setiap hari selain sholat sunnat ialah membaca amalan berikut:

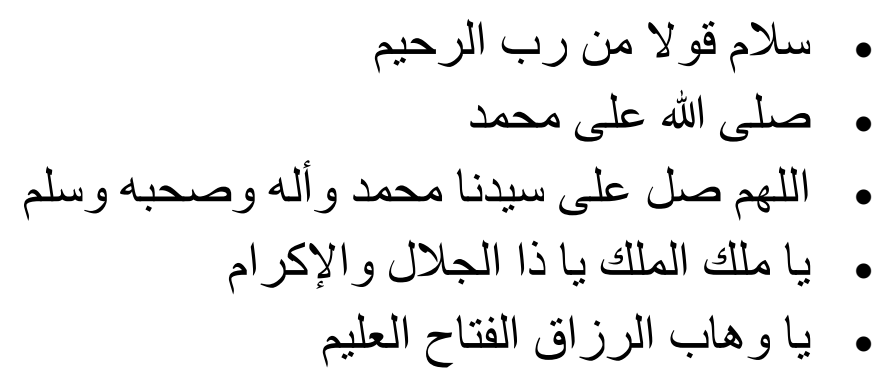

Masing-masing Ini dibaca sebanyak 300 kali setelah selesai sholat.

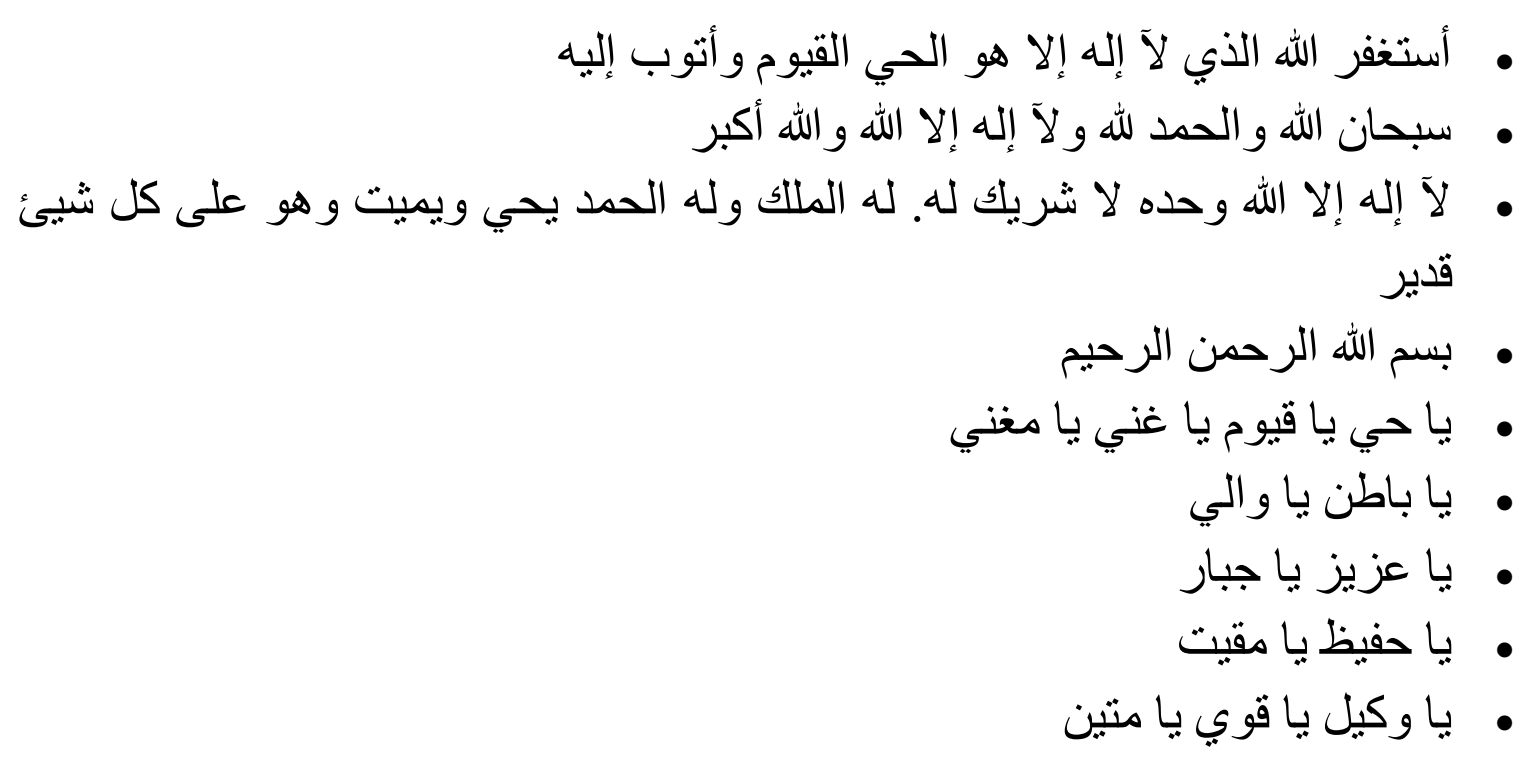

Setelah selesai sholat masing-masing dibaca sebanya 100 kali.

Dibaca sebanyak 1000 kali setelah selesai sholat.

Al Qalam: Jurnal Ilmiah Keagamaan dan Kemasyarakatan Vol. 16, No. 1

Januari - Juni 2022 
Amalan-amalan diatas disusun oleh Arni sendiri berdasarkan dari pengetahuannya dan guru-gurnya, serta arni sendiri mengatakan dia tidak memiliki guru secara khusus seperti yang ajarkan dalam tarekat yaitu seperti Mursyid ataupun semacamnya. Disisi lain ada juga amalanamalan yang dibaca diluar dari saat-saat tersebut, diantaranya Al-Fatihah sebanyak 41 kali, Surah Taha ayat 1-8 sebanyak 3 kali, Laqadzā akum hingga Akhir ayat dan Asmaul Husna. Dirinya juga sering membaca Surah Al-Fatihah, Al-Ikhlas, Al-Falaq dan An-Nâs untuk menghadiahi Ibu, Nenek dan Moyang serta para auliya seperti Syekh Semman Al-Madani, Syekh Arsyad Al-Banjari, Imam Al-Ghazali, Guru Zaini bin Abdul Ghani dan lain-lainya. ${ }^{21}$

\section{Analisis}

Jika dilihat dari media yang digunakan oleh Arni dalam batatamba seperti air untuk diminum dan tiupan secara langsung kepada pasien, maka hal tersebut sejalan dengan apa yang telah Rasulullah Saw lakukan, baik itu untuk pribadi maupun untuk orang lain. Akan tetapi jika diamati lebih lanjut terdapat satu media yang unik, dimana Arni menggunakan telepon seluler sebagai sarana untuk pasien yang berada di tempat yang jauh, sehingga hal tersebut menjadi kemudahan bagi pasien ataupun orang lain yang memerlukan sesuatu. Maka dari sini dapat dilihat bahwa batatamba Arni tidak hanya terbatas pada sesuatu yang mengaharuskan berjumpa antara pasien dengan yang mengobati, akan tetapi batatamba Arni juga mampu berkembang dan menyesuaikan kondisi sebagai bentuk perubahan dalam kemudahan untuk batatamba.

Adapun bacaan-bacaan yang digunakan Arni seperti Surah Al-Fatihah, Ayat Kursiy, surah Al-Falaq, dan Surah An-Nâs serta ayat-ayat tertentu, maka tidak ada yang menyalahi dari yang sebagaimana telah dipraktikan oleh Rasulullah Saw. Meskipun ada sedikit perbedaan dengan adanya penambahan bacaan pada pasien tertentu, tetapi hal tersebut juga tidak menjadi persoalan, sebab Arni melakukan penambahan bacaan yang berasal dari Al-Qur'an. Hal tersebut diperkuat sebagaimana yang dijelaskan oleh Ibnu Hajar Al- Asqalani sebagai berikut:

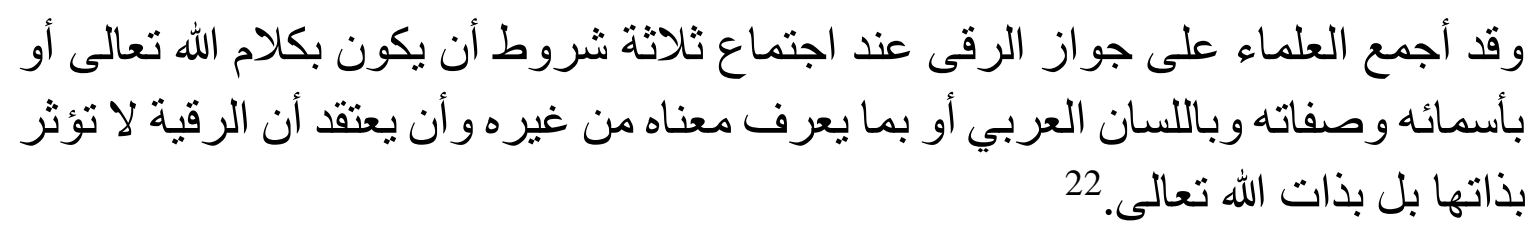

Artinya: ulama telah sepakat boleh melakukan pengobatan dengan ruqyah jika memenuhi tiga syarat, pertama, menggunakan kalam Allah, nama-nama dan sifat-sifat-Nya. Kedua, menggunakan

\footnotetext{
${ }^{21}$ Wawancara pribadi dengan Arni, Banjarmasin tanggal 19 Desember 2020.

${ }^{22}$ Ibn Hajar al-'Asqalanī, Fathul Bārî, Jilid 10 (Beirut: Dār Al-Makrifah, 1379 M), 195.

Al Qalam: Jurnal Ilmiah Keagamaan dan Kemasyarakatan Vol. 16, No. 1 Januari - Juni 2022
} 
bahasa arab atau yang diketahui maknanya. Ketiga, berkeyakinan bahwasanya ruqyah tidak memberi pengaruh dengan sendirinya, akan tetapi dengan kekuasaan Allah Swt.

Dari ungkapan diatas telah jelas bahwa seperti apapun bentuk bacaan yang digunakan dalam batatamba dan selama memenuhi tiga syarat tersebut, maka tentu diperbolehkan dalam melaksanakannya. Oleh karena itulah, jika diamati dari bentuk dan metode Arni dalam batatamba serta melihat latar belakang penddikan yang ditempuh hingga menjadi seorang akademisi, maka tidak mengherankan bahwa yang dilakukan Arni dalam batatamba benar-benar hampir sama sebagaimana yang dilakukan oleh Rasulullah Saw di dalam haditsnya, sebab seorang akademisi cenderung lebih selektif dalam memilih, baik itu bentuk, metode maupun bacaan yang digunakan dalam batatamba.

Sedangkan dari sisi amalan dan konsekuensi dalam spiritual, Arni tidak lepas dari pemahaman konsep sufi yang sudah menjadi tradisi, yakni takhalli sebagai bentuk kesucian diri, tahalli sebagai bentuk perhiasan diri dan tajalli sebagai bentuk perolehan hasil dari kedua konsep sebelumnya sehingga mampu menyaksikan segala kebenaran yang selama ini terhalang bagi dirinya.

Jika diamati, amalan Arni dalam batatamba mengandung dua konsep sufi sebelumnya, yakni takhalli dan tahalli. Oleh karena dirinya mengetahui bahwa amalan-amalan yang dibaca bertujuan agar membuat dirinya kokoh dan terhindar dari gangguan jin yang berasal dari pasien yang dia tangani, maka Arni lebih menekankan keistiqomahanan dalam amalan-amalan sunnah seperti sholat-sholat sunnah, dzikir, sholawat dan lain-lainnya. Sehingga, hal tersebut bisa dipahami bahwa istiqomah yang merupakan bagian dari konsep tahalli adalah salah satu upaya untuk menjaga dan mebentengi diri. Sedangkan konsep takhalli terlihat saat Arni membaca istigfar setiap harinya sebagai bentuk kewaspadaan jika dirinya tidak menyadari telah berbuat suatu kesalahan atau kekeliruan dalam kesehariannya.

Tidak bisa dipugkiri bahwa istilah Istiqomah terkenal di berbagai kalangan, dari awam hingga ulama, dan jika ditelaah lebih lanjut, terdapat banyak keutamaan dalam praktik istiqomah, Diantaranya seperti yang dialami oleh Abu Ali Asy-syabbuwi, bahwa dirinya bermimpi dengan Rasulullah kemudian dia bertanya "Dikabarkan bahwa paduka bersabda, "Surat Huud telah membuat rambutku menjadi putih. Apakah (Rambut paduka menjadi putih karena) kisah-kisah para nabi ataukah karena dimusnahkannya umat-umat (zaman dahulu)?, beliau menjawab, Bukan, melainkan karena firman Allah SWT.:

Al Qalam: Jurnal Ilmiah Keagamaan dan Kemasyarakatan Vol. 16, No. 1 Januari - Juni 2022 


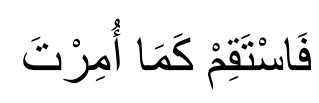

Artinya: "Maka beristiqamahlah kamu sebagaimana kamu telah diperintahkan”. (QS. Huud/ 11: 112). ${ }^{23}$

Begitupula didalam hadits disebutkan tetang anjuran istiqomah sebagai berikut:

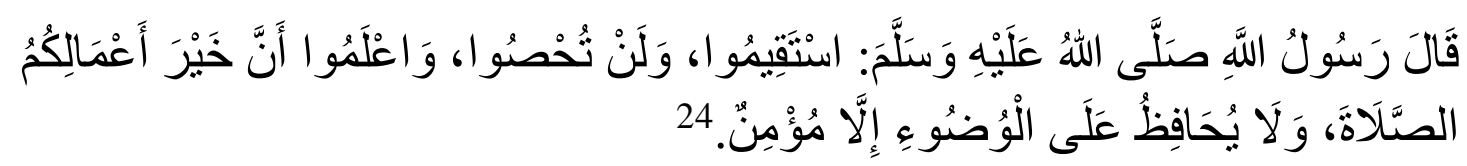

Artinya: Rasulullah Bersabda "Beristiqamahlah (berteguh hatilah) kamu sekalian, dan janganlah sekali-kali menghitung-hitung (amalmu)", ketahuilah bahwa amalan terbaik adalah Sholat dan menjaga Wudhu.

Berdasarkan keterangan diatas dijelaskan bahwa begitu besar dan berharganya anjuran istiqomah. Oleh sebab itulah, tidak mengherankan bahwa istiqomah yang ditekan oleh Arni memiliki dampak yang begitu besar terutama pada persoalan batatamba yang tidak hanya cukup bermodalkan dengan suara dan keberanian, tetapi juga harus diikuti dengan istiqomahnya sebuah amalan.

Adapun konsekuensi ataupun implikasi yang didapat dari sebuah amalan-amalan yang dilaksanakan oleh Arni, merupakan buah dari amalan yang telah dirinya laksanakan sebagaimana tajalli yang akan diperoleh dengan melalui takhalli dan tahalli terlebih dahulu. Diantara implikasi dari amalan yang telah dijalaninya ialah seperti bermimpi dengan Rasulullah, Malaikat dan Ulama (Guru Sekumpul) sebagaimana yang pernah dialami oleh para tokoh-tokoh sufi terdahulu, ada banyak sekali cerita para sufi ketika bermimpi, baik itu berjumpa dengan Rasulullah, Malaikat ataupun Ulama yang telah terdahulu wafatnya, diantaranya seperti yang dialami oleh Al-Katani salah satu tokoh sufi dimasanya sebagai berikut:

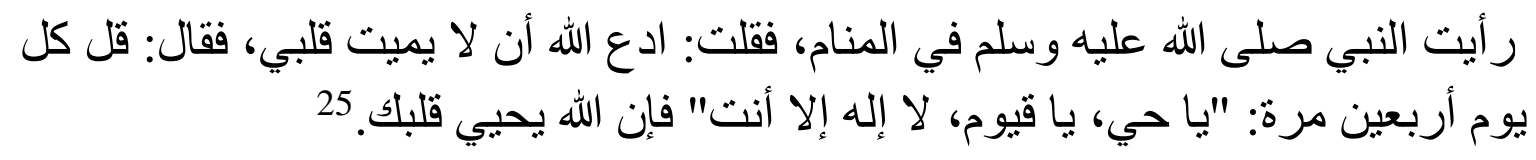

Artinya: Aku bertemu dengan Rasulullah didalam mimpi, lalu aku berkata "doakanlah agar hatiku tidak mati”, kemudia Rasulullah bersabda "Bacalah (Yā Hayyu Yā Qayyum Lā Ilāha Illā Anta) sebanyak 40 kali setiap hari" maka Allah Swt senantiasa menghidupkan (ketenangan) Hatimu.

\footnotetext{
${ }^{23}$ Abdul Halim Mahmud, Tasawuf di Dunia Islam (Bandung: CV Pustaka Setia, 2002), 221.

${ }^{24}$ Abū 'Abdillah Muhammad bin Yazĩd, Sunan Ibnu Majah Jilid 1 (Al-Qāhirah: Dār Ihyā Al-Kutub Al- 'Arabiyah, tth), 101.

${ }^{25}$ Al-Qushayri, Al- Risalah Al- Qusayriyah (Beirut: Dar Al-kotob Al- Ilmiyah, 2013), 417.

Al Qalam: Jurnal Ilmiah Keagamaan dan Kemasyarakatan Vol. 16, No. 1 Januari - Juni 2022
} 
Begitu pula yang dialami oleh Ibrāhim bin Adham ketika bermimpi dengan malaikat Jibril As sebagai berikut:

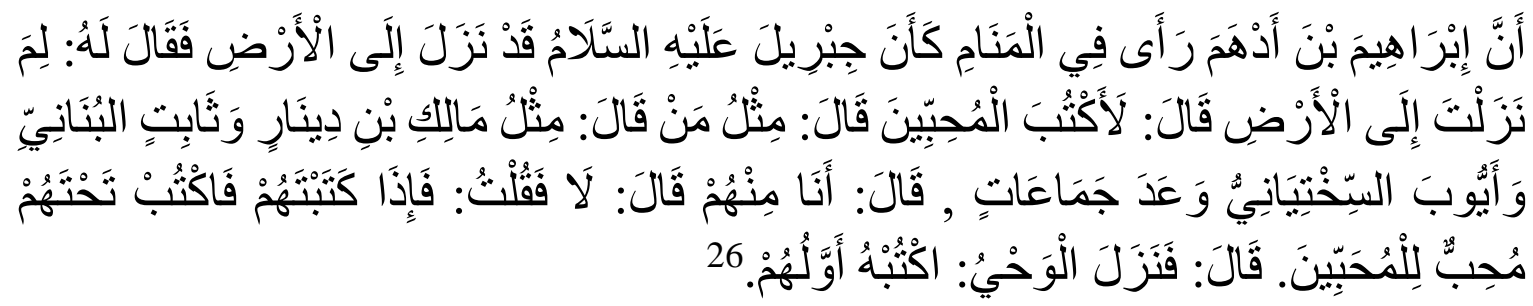

Artinya: Bahwa Ibrāhim bin Adham melihat didalam mimpinya seakan-akan malaikat Jibril turun ke bumi, lalu Ibrāhim bin Adham berkata "untuk apa kamu turun ke bumi”, Jibril menjawab "untuk menuliskan orang-orang yang senantiasa cinta", kemudian Ibrāhim bin Adham berkata "seperti siapa”. Jibril menjawab "seperti Mālik bin Dinār, Tsābit Al-Bunānì dan Ayyūb As-Sikhtiyāni dan orang-orang telah dijanjikan", selanjutnya Ibrāhim bin Adham berkata "Apakah aku termasuk disana”, Jibril berkata "tidak" lalu Ibrāhim bin Adham berkata "apabila kamu menulis mereka, maka tulislah pula dibawahnya orang-orang yang cinta terhadap orang-orang yang senantiasa cinta", lalu Jibril berkata "telah turun wahyu dan Tulislah dia (Ibrähim bin Adham) yang pertama diantara mereka."

Begitu pula bermimpi dengan ulama, ada banyak sekali riwayat ataupun cerita didalam buku-buku para sufi yang menuliskan pengalaman mereka ketika bermimpi. Diantaranya seperti Sufyan bin Uyainah yang bermimpi dengan Sufyan At-Tsauri dari salah satu Tãbi'ut Tãbi'in sebagai berikut:

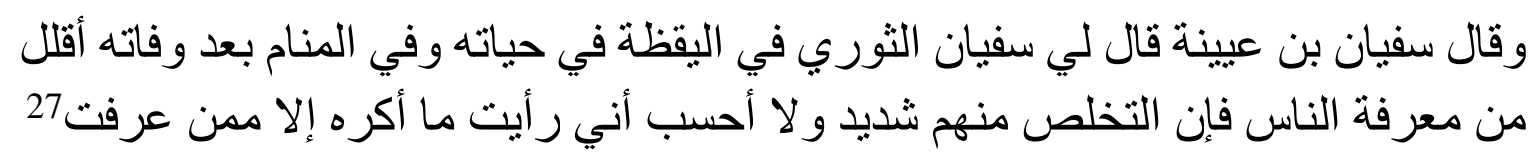

Artinya: Telah berkata Sufyan bin Uyainah telah berkata kepada ku Sufyan At-Tsauri ketika aku terjaga dan didalam mimpi, "Aku memperkecil hubungan dengan manusia, karena melepaskan diri dari mereka adalah hal yang sulit dan aku tidak mengira bahwa aku melihat sesuatu yang sangat aku benci kecuali dari seseorang yang telah aku kenali"

Dari kutipan ini dapat disimpulkan bahwa bermimpi Rasulullah, malaikat ataupun ulama bukanlah sesuatu yang baru, tetapi sudah pernah terjadi dimasa-masa para sufi terdahulu. Sehingga apa yang dikatakan oleh Arni tentang mimpi-mimpinya memiliki dasar yang kuat jika ditinjau dari

\footnotetext{
${ }^{26}$ Abū Nu'aim Ahmad Bin Abdillah, Hilyatul Auliyā wa Thabaqātul Asfiyā Jilid 8 (Beirut: Dār AlKitāb Al- 'Arabiy, 1974), 34.

${ }^{27}$ Abū Hāmid Muhammad Al-Ghazāli, Ihya Ulumiddin Jilid 2 (Beirut: Dār Al-Ma'rifah, tth), 234.

Al Qalam: Jurnal Ilmiah Keagamaan dan Kemasyarakatan Vol. 16, No. 1 Januari - Juni 2022
} 
kisah-kisah para sufi terdahulu. Oleh karena itulah, maka hal tersebut berkaitan erat sebagaimana konsep yang telah diungkapkan al-Ghazali sebagai tahapan akhir dari proses seorang sufi dalam beramal, yaitu (tajalli) menyaksikan segala hakikat yang selama ini terhalangi oleh kotoran jiwa, baik itu diperoleh melalui bermimpi dengan seseorang yang amat mulia ataupun dengan yang selainnya.

\section{KESIMPULAN}

Berdasarkan paparan diatas dapat disimpulkan bahwa bentuk dan metode Arni dalam batatamba menggunakan media Air dan Tiupan sebagaimana yang sudah pernah dicontohkan oleh Rasulullah Saw. Namun terdepat sedikit keunikan bahwa Arni juga bisa menggunakan sarana telepon seluler dalam batatamba bagi pasien yang sedang berada di tempat jauh.

Adapun dengan bacaan-bacaannya terhadap pasien seperti Al-Fatihah, Ayat Kursyi, surah Al-Falaq dan An-Nâs serta ayat-ayat tertentu didalam Al-Qur'an, maka hal ini juga sejalan dengan apa yang telah dipraktikan oleh Rasulullah Saw ketika dirinya sedang mengobati sahabat yang sedang sakit ataupun untuk dirinya sendiri.

Sedangkan amalan-amalanya seperti berbagai macam Sholat Sunnah, Dzikir, Sholawat dan istigfar, selaras dengan konsep sufi yang telah dikemukan al-Ghazali yaitu takhalli, tahalli dan tajalli, sehingga berimplikasi mampu bermimpi dengan Rasulullah, Malaikat dan ulama sebagai bentuk perwujudan konsep tajalli sebagaimana yang pernah dialami oleh para sufi terdahulu. Oleh sebab itulah dapat disimpulkan bahwa praktik Arni ketika batatamba tidak bertentangan dengan ajaran Islam serta didalamnya juga sejalan dengan nilai ataupun konsep sufi dalam spiritual.

\section{DAFTAR PUSTAKA}

Abdullah Al-Sadhan, Cara Pengobatan Dengan Al-Qur'an diterjemahkan oleh Muzaffar Sahidu dari كيف تعالج مربضم بالرقبة الثر عية, Indonesia: ttp, 2009.

Ahmad, Abū Nu'aim Bin Abdillah, Hilyatul Auliyā wa Thabaqātul Asfiyā Jilid 8, Beirut: Dār AlKitāb Al- 'Arabiy, 1974.

Al- 'Asqalanī, Ibn Hajar, Fathul Bārî, Jilid 10, Beirut: Dār Al-Makrifah, 1379 M.

Al-Ghazāli, Abū Hāmid Muhammad, Ihya Ulumiddin Jilid 2, Beirut: Dār Al-Ma'rifah, tth.

Al-Qushayri, Al-Risalah Al-Qusayriyah, Beirut: Dar Al-kotob Al-Ilmiyah, 2013.

Arni, Implementasi Ruqyah Syar'iyah Sebegai Alternatif Psikoterapi Dalam Kajian Psikologi Islam, Jurnal Studia Insania, Vol. 9, No.1, 2021.

Arni, Kepercayaan Bagampiran Antara Manusia dengan Makhluk Gaib Di Amuntai, Jurnal Ilmu Ushuluddin, Volume 9, No. 1, Januari 2010.

Asmaran, Pengantar Studi Tasaawuf, Jakarta: PT RajaGrafindo Persada, 1996.

\section{Al Qalam: Jurnal Ilmiah Keagamaan dan Kemasyarakatan Vol. 16, No. 1 Januari - Juni 2022}


Asmawati, Zaenap Hartati dan Emawati, Makna Pengobatan Tradisional Badewah Suku Dayak Bagi Masyarakat Muslim di Kalimantan Tengah, Jurnal IAIN Palangka Raya Studi Agamaagama, Volume 8, Nomor 1, 2018.

Jamalie, Zulfa dan Muhammad Rif'at, Dakwah Kultural (Dialektika Islam dan Budaya dalam Tradisi Batatamba), Jurnal IAIN Antasari Banjarmasin AL-HADHARAH, Volume 11, Nomor 21, 2012.

Laila Afiyatin Alfiyah, Ruqyah Sebagai Pengobatan Berbasis Spiritual Untuk Mengatasi Kesurupan, Jurnal HISBAH, Vol. 16, No. 2, 2019.

Madya dan Awang Azman, Warisan dan Sumber: Pengertian Sejarah, Budaya dan Alam Borneokalimantan, Malaysia: Bumi Serasi, 2012.

Mahmud, Abdul Halim, Tasawuf di Dunia Islam, Bandung: CV Pustaka Setia, 2002.

Muhammad Bin Ismâ'îl Al-Bukhârî, Shahîh Al-Bukhârî Jilid 7, Beirut: Dâr Thûq An-Najâh, 1422.

Muhammad, Abū 'Abdillah bin Yazĩd, Sunan Ibnu Majah Jilid 1, Al-Qāhirah: Dār Ihyā Al- Kutub Al- 'Arabiyah, tth.

Muhammad, Abu 'Abdullah bin Ismāīl al-Bukharī, Al-Jāmī’ Al-Shahīh, Volume IV, Kairo: alMathba'ah as-Salafiyyah, 1400.

Muslim, Shahîh Muslim Jilid 4, Beirut: Dâr Ihyâ’ At- Turâts Al-'Arabîy, t.th.

Nur Syaifan, Sufi Healing Praktek Pengobatan Spiritual Di Desa Cangkrep Kabupaten Purworejo, Jurnal Refleksi, Vol. 15, No.1, 2015.

Rusandi, M. Arli dan Ledya Oktavia Liza, Nilai-nilai Batatamba Masyarakat Banjar Bantaran Sungai dalam Mengatasi Gangguan Psikologis (Gelisah dan Gangguan Tidur) kedalam Bimbingan dan Konseling, Jurnal Universitas Negeri Semarang, 2017.

Sulaiman, Abū Dāud, Sunan Abị Dāud Jilid 6, Lebanon: Dār Ar- Risālah Al-'Ālamiyah, 2009.

Syukur, M. Amin SUFI HEALING; Terapi dalam Literatur Tasawuf, Jurnal IAIN Walisongo Semarang Volume 20, Nomor 2, 2012.

Al Qalam: Jurnal Ilmiah Keagamaan dan Kemasyarakatan Vol. 16, No. 1

Januari - Juni 2022 